Supporting Information

\title{
In vivo proteome of Pseudomonas aeruginosa in airways of cystic fibrosis patients
}

Xia Wu${ }^{1}$, Richard J Siehnel ${ }^{2}$, Jayanthi Garudathri ${ }^{2}$, Benjamin J. Staudinger ${ }^{3}$, Katherine B. Hisert ${ }^{3}$, Egon A. Ozer ${ }^{5}$, Alan R. Hauser ${ }^{5}$, Jimmy K. Eng ${ }^{1}$, Colin Manoil ${ }^{1}$, Pradeep K. Singh ${ }^{2,3}$, James E. Bruce ${ }^{1,4, *}$

${ }^{1}$ Department of Genome Sciences, University of Washington, Seattle, WA, USA.

${ }^{2}$ Department of Microbiology, University of Washington, Seattle, WA, USA.

${ }^{3}$ Department of Medicine, University of Washington, Seattle, WA, USA.

${ }^{4}$ Department of Chemistry, University of Washington, Seattle, WA, USA.

${ }^{5}$ Department of Microbiology-Immunology, and Department of Medicine, Northwestern University, Chicago, Illinois, USA.

*To whom correspondence should be addressed: James E. Bruce, Department of Genome Sciences, University of Washington, 850 Republican Street, Seattle, WA 98109. Tel: (206)543-0220; Fax: (206)

616-0008; E-mail: jimbruce@u.washington.edu 


\section{SUPPORTING INFORMATION TABLE OF CONTENTS}

The following supporting information is available free of charge at ACS website

http://pubs.acs.org

SUPPLEMENTAL MATERIALS AND METHODS

S-3 to S-6

Figure S1. PA proteins are much less abundant compared with human proteins in CF sputum samples.

Figure S2. Treatment with $0.1 \%$ Triton X-100 or $0.1 \%$ Brij 58 did not lyse viable PA cells. S-8

Figure S3. Comparison of PA proteome before and after the bacterial-enrichment procedures.

S-9, S-10

Figure S4. PA protein network up-regulated (A) or down-regulated (B) in CF airways.

S-11, S-12

Figure S5. Carbon metabolic remodeling of PA in vivo.

S-13 to $S-15$

Figure S6. Spectrum examples of parallel reaction monitoring (PRM) assays to detect PA

proteins with CF sputum samples.

S-16 to S-18

Table S1. CF sputum sample information.

Table S2. The identified PA proteins with CF sputum samples. 


\section{SUPPLEMENTAL MATERIALS AND METHODS}

\section{Immunoblot analysis and antibody information}

Proteins were extracted from CF sputum samples with 4x Laemmli protein sample buffer (Bio-Rad, Hercules, CA, USA). Extraction mixtures were incubated at $95^{\circ} \mathrm{C}$ with a heating block for 5 min. The extraction mixtures were further vortexed for $30 \mathrm{~s}$, and were sonicated with a GE-130 ultrasonic processor using settings of $50 \%$ amplitude, $30 \mathrm{~s}$ duration for two cycles. Protein concentration was estimated with Bradford assay. As SDS could interfere with the accuracy of Bradford assay protein quantitation, two rounds of SDS-PAGE were analyzed. At the first round of SDS-PAGE, SDS was removed through three washes of SDS-PAGE gel with $\mathrm{H}_{2} \mathrm{O}$, and gels were stained with coomassie blue (Bio-Rad). The densitometry of each lane was obtained with Odyssey Infrared Imaging System (LI-COR Bioscience). The densitometry information was used for further adjustment of equal total protein loading. At the second round of SDS-PAGE, equal total proteins were loaded based on the updated information, and gels were transferred to Immobilon-FL PVDF for immunoblot analysis (1).

Antibodies for human protein anti-GAPDH were purchased from Genscript (catalog information, A00191) (Piscataway, NJ, USA). Antibodies for bacterial protein anti-TufA was obtained from Hycult Biotech Inc. (Plymouth Meeting, PA, USA) (catalog information, HM6010). Antibodies for bacterial protein anti-RpoA was purchased from Neoclone (Madison, WI, USA) (catalog information, SP002W0003).

\section{Proteins subsets with single PA peptide identification}

First, there were 248 PA proteins that were identified with one peptide from a single CF sputum sample, but with two or more peptides across the entire $35 \mathrm{CF}$ sputum sample set. While these identifications did not provide the same level of confidence as derived from 2 identified peptides from a single sputum sample, the two separate peptide IDs from the entire dataset (1) improve confidence that 
the protein is expressed in patient airways and (2) provide independent opportunities that can be used for the targeted PRM methods for quantification of these proteins in sputum.

The second sub-group contains 82 PA proteins with single peptide ID's that have been repeatedly identified in 3 or more sputum samples and identified with at least two peptides from ex vivo samples. Of the 82 PA proteins identified in patient airway samples with only a single peptide, 44 of these same peptides were identified together with at least one other non-redundant peptide from the same protein in ex vivo PA samples, increasing the likelihood of the presence of these proteins in patient airway samples. The in vitro IDs indicate that the PA peptides can be identified without the host materials, meaning that the protein extraction and digestion method, LC-MS/MS system, and database search method were tuned to identify these peptides. The in vivo PA peptide IDs may be truly from the PA proteins rather than coming from the incorrect assignment of the host proteins/peptides.

All presented PA peptides are unique to PA against human proteins.

\section{Accession number of PA genome}

PA genome sequence deposited to National Center for Biotechnology Information (NCBI) are as follow.

$\begin{array}{ll}\text { Organism } & \text { Accession } \\ & \\ \text { PABL001 } & \text { QVEI00000000 } \\ \text { PABL002 } & \text { QVEH00000000 } \\ \text { PABL003 } & \text { QVEG00000000 } \\ \text { PABL004 } & \text { QVEF00000000 } \\ \text { PABL006 } & \text { QVEE00000000 } \\ \text { PABL007 } & \text { QVED00000000 } \\ \text { PABL009 } & \text { QVEC00000000 } \\ \text { PABL010 } & \text { QVEB00000000 } \\ \text { PABL011 } & \text { QVEA00000000 } \\ \text { PABL012 } & \text { CP031659 } \\ \text { PABL013 } & \text { QVDZ00000000 } \\ \text { PABL014 } & \text { QVDY00000000 } \\ \text { PABL015 } & \text { QVDX00000000 } \\ \text { PABL016 } & \text { QVDW00000000 } \\ \text { PABL017 } & \text { CP031660 } \\ \text { PABL018 } & \text { QVDV00000000 } \\ \text { PABL019 } & \text { QVDU00000000 } \\ \text { PABL020 } & \text { QVDT00000000 }\end{array}$




\begin{tabular}{|c|c|}
\hline PABL021 & QVDS00000000 \\
\hline PABL022 & QVDR00000000 \\
\hline PABL023 & QVDQ00000000 \\
\hline PABL024 & QVDP00000000 \\
\hline PABL026 & QVDO00000000 \\
\hline PABL027 & QVDN00000000 \\
\hline PABL028 & QVDM00000000 \\
\hline PABL029 & QVDL00000000 \\
\hline PABL030 & QVDK00000000 \\
\hline PABL031 & QVDJ00000000 \\
\hline PABL032 & QVDI00000000 \\
\hline PABL034 & QVDH00000000 \\
\hline PABL035 & QVDG00000000 \\
\hline PABL036 & QVDF00000000 \\
\hline PABL037 & QVDE00000000 \\
\hline PABL038 & QVDD00000000 \\
\hline PABL040 & QVDC00000000 \\
\hline PABL041 & QVDB00000000 \\
\hline PABL042 & QVDA00000000 \\
\hline PABL043 & QVCZ00000000 \\
\hline PABL044 & QVCY00000000 \\
\hline PABL045 & QVCX00000000 \\
\hline PABL046 & QVCW00000000 \\
\hline PABL047 & QVCV00000000 \\
\hline PABL048 & QVCU00000000 \\
\hline PABL049 & QVCT00000000 \\
\hline PABL051 & QVCS00000000 \\
\hline PABL052 & QVCR00000000 \\
\hline PABL053 & QVCQ00000000 \\
\hline PABL054 & QVCP00000000 \\
\hline PABL055 & QVCO00000000 \\
\hline PABL056 & QVCN00000000 \\
\hline PABL057 & QVCM00000000 \\
\hline PABL058 & QVCL00000000 \\
\hline PABL059 & QVCK00000000 \\
\hline PABL060 & QVCJ00000000 \\
\hline PABL061 & QVCI00000000 \\
\hline PABL062 & QVCH00000000 \\
\hline PABL063 & QVCG00000000 \\
\hline PABL064 & QVCF00000000 \\
\hline PABL065 & QVCE00000000 \\
\hline PABL066 & QVCD00000000 \\
\hline PABL067 & QVCC00000000 \\
\hline PABL068 & QVCB00000000 \\
\hline PABL069 & QVCA00000000 \\
\hline PABL070 & QVBZ00000000 \\
\hline PABL071 & QVBY00000000 \\
\hline PABL072 & QVBX00000000 \\
\hline PABL073 & QVBW00000000 \\
\hline PABL074 & QVBV00000000 \\
\hline
\end{tabular}




$\begin{array}{ll}\text { PABL075 } & \text { QVBU00000000 } \\ \text { PABL076 } & \text { QVBT00000000 } \\ \text { PABL077 } & \text { QVBS00000000 } \\ \text { PABL078 } & \text { QVBR00000000 } \\ \text { PABL079 } & \text { QVBQ00000000 } \\ \text { PABL080 } & \text { QVBP00000000 } \\ \text { PABL081 } & \text { QVBO00000000 } \\ \text { PABL082 } & \text { QVBN00000000 } \\ \text { PABL083 } & \text { QVBM00000000 } \\ \text { PABL084 } & \text { QVBL00000000 } \\ \text { PABL085 } & \text { QVBK00000000 } \\ \text { PABL086 } & \text { QVBJ00000000 } \\ \text { PABL088 } & \text { QVBI00000000 } \\ \text { PABL089 } & \text { QVBH00000000 } \\ \text { PABL090 } & \text { QVBG00000000 } \\ \text { PABL091 } & \text { QVBF00000000 } \\ \text { PABL092 } & \text { QVBE00000000 } \\ \text { PABL093 } & \text { QVBD00000000 } \\ \text { PABL094 } & \text { QVBC00000000 } \\ \text { PABL095 } & \text { QVBB00000000 } \\ \text { PABL096 } & \text { QVBA00000000 } \\ \text { PABL097 } & \text { QVAZ00000000 } \\ \text { PABL098 } & \text { QVAY00000000 } \\ \text { PABL100 } & \text { QVAX00000000 } \\ \text { PABL101 } & \text { QVAW00000000 } \\ \text { PABL102 } & \text { QVAV00000000 } \\ \text { PABL103 } & \text { QVAU00000000 } \\ \text { PABL104 } & \text { QVAT00000000 } \\ \text { PABL105 } & \text { QVAS00000000 } \\ \text { PABL106 } & \text { QVAR00000000 } \\ \text { PABL107 } & \text { QVAQ00000000 } \\ \text { PABL108 } & \text { QVAP00000000 }\end{array}$

\section{SUPPLEMENTAL REFERENCES}

1. Wu, X.; Chavez, J. D.; Schweppe, D. K.; Zheng, C.; Weisbrod, C. R.; Eng, J. K.; Murali, A.; Lee, S. A.; Ramage, E.; Gallagher, L. A.; Kulasekara, H. D.; Edrozo, M. E.; Kamischke, C. N.; Brittnacher, M. J.; Miller, S. I.; Singh, P. K.; Manoil, C.; Bruce, J. E., In vivo protein interaction network analysis reveals porin-localized antibiotic inactivation in Acinetobacter baumannii strain AB5075. Nat Commun 2016, 7, 13414. 
Figure $\mathbf{S 1}$
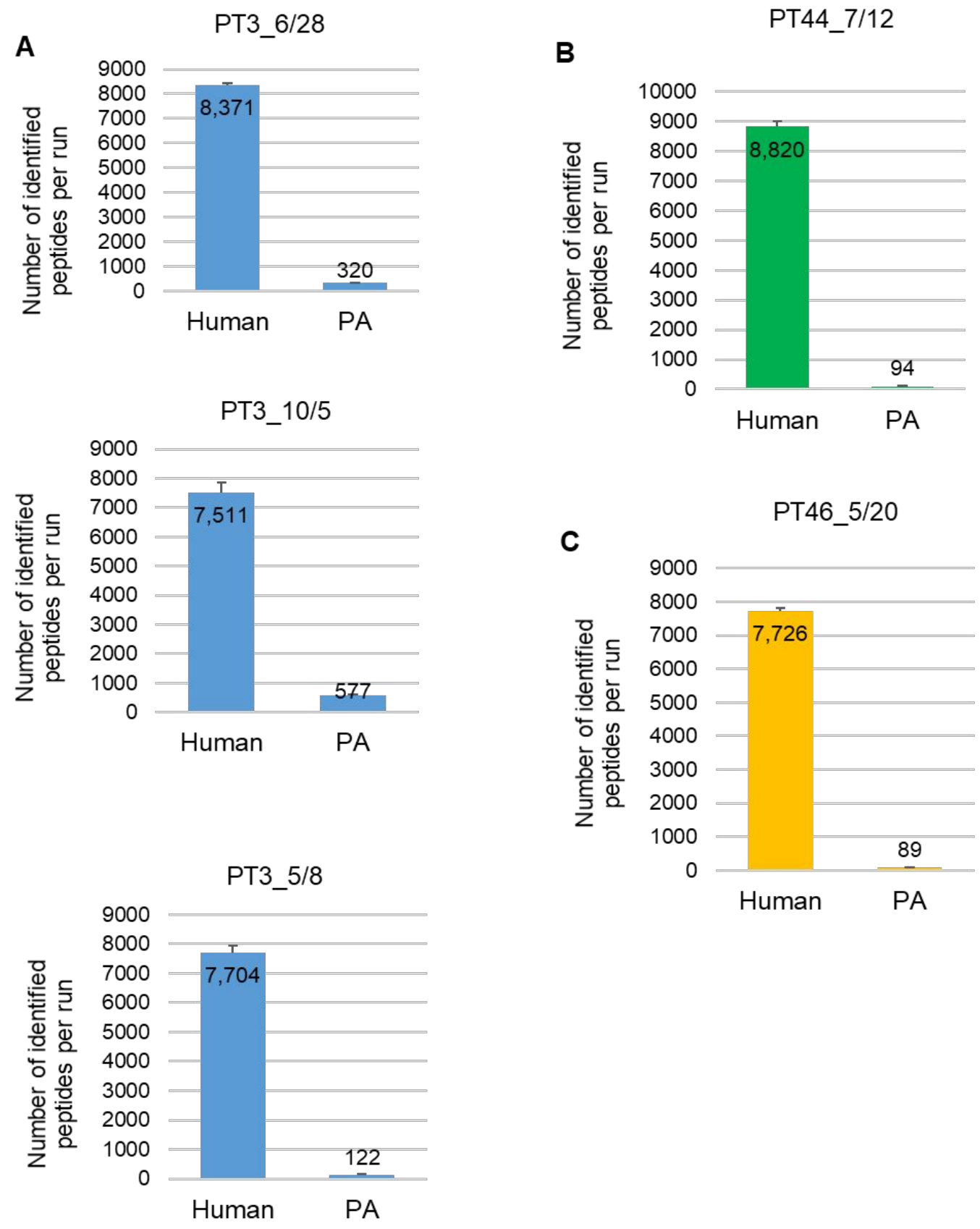

Figure S1. PA proteins are much less abundant compared with human proteins in CF sputum samples. The number of non-redundant human or PA peptides identified in each LC-MS/MS run is shown. Examples include five CF sputum samples collected from three CF patients (A, B, C). The low abundance of PA proteins in CF sputum samples highlights the necessity to design bacterial-enrichment methods to improve PA protein identification with $\mathrm{CF}$ sputum samples. 

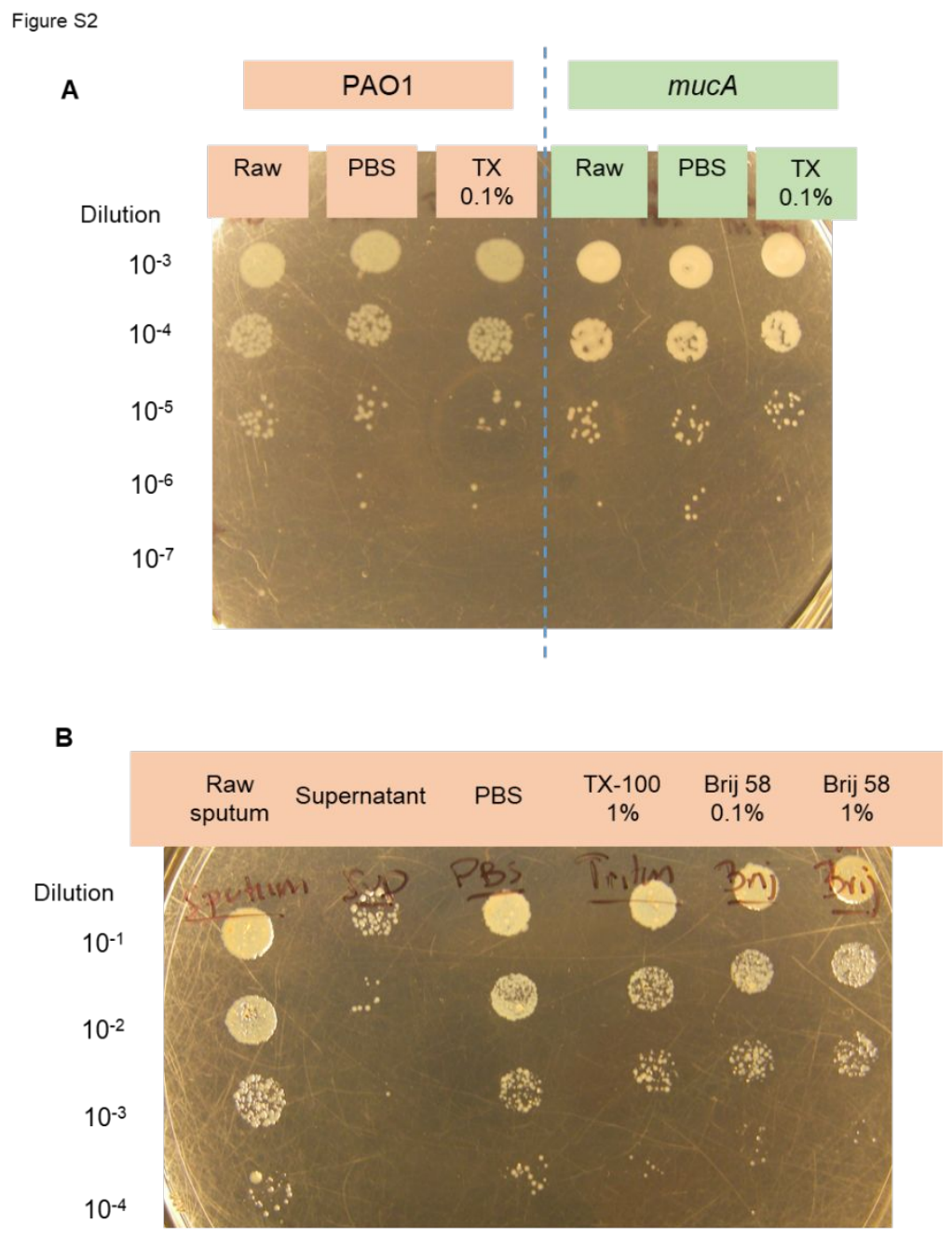

Figure S2. Treatment with $0.1 \%$ Triton $\mathrm{X}-100$ or $0.1 \%$ Brij 58 did not lyse viable PA cells. A). P. aeruginosa PAO1 WT or mucA strain (mucoid phenotype, Mathee et al., 1999) of $\mathrm{OD}_{600}=1.0$ were subjected to centrifugation (10, $000 \times \mathrm{g}, 5 \mathrm{~min}$ ) and resuspension treatment (PBS or TX-100 0.1\%). The "Raw" cells are control samples that did not undergo centrifugation and PBS/TX-100 treatment procedures. CFU analysis shows that PBS and TX-100 treatment did not cause lysis of PAO1 and mucA cells. B) CF sputum samples were homogenized with PBS and $0.1 \%$ dithiothreitol on ice for $30 \mathrm{~min}$, and aliquotted to five tubes. The sputum pellet (after $10 \mathrm{~min}, 16,000 \times \mathrm{g}, 4^{\circ} \mathrm{C}$ ) was resuspended with PBS, $1 \%$ TX-100, $0.1 \%$ Brij 58 or $1 \%$ Brij 58. The resuspension mixtures were centrifuged again with $16,000 \times \mathrm{g}$, and resuspended to the original volume with PBS for CFU analysis. The "Raw sputum" was the sample aliquot that was homogenized but was not subjected to centrifugation and detergent treatment analyses. The "Supernatant" was the supernatant fraction collected after the first found of $16,000 \times \mathrm{g}$ centrifugation. Results indicate that treatment of PBS, $1 \%$ TX-100, $0.1 \%$ or $1 \%$ Brij 58 did not lyse viable bacterial cells in CF sputum samples. The CFU in the supernatant fraction shows that approximately $1 \%$ (two $\log 10$ reduction) of bacterial cells remained in the supernatants after the centrifugation procedures. 
Figure S3

A

Sputum sample 1

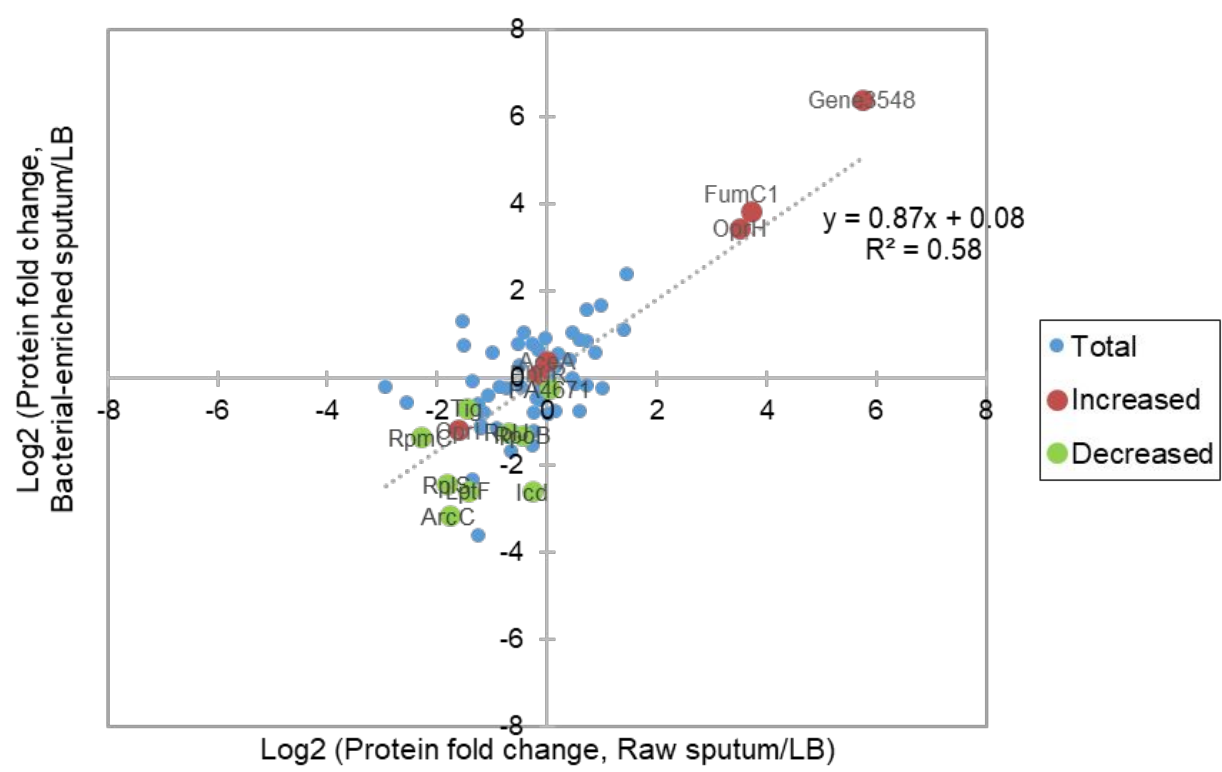

Sputum sample 2

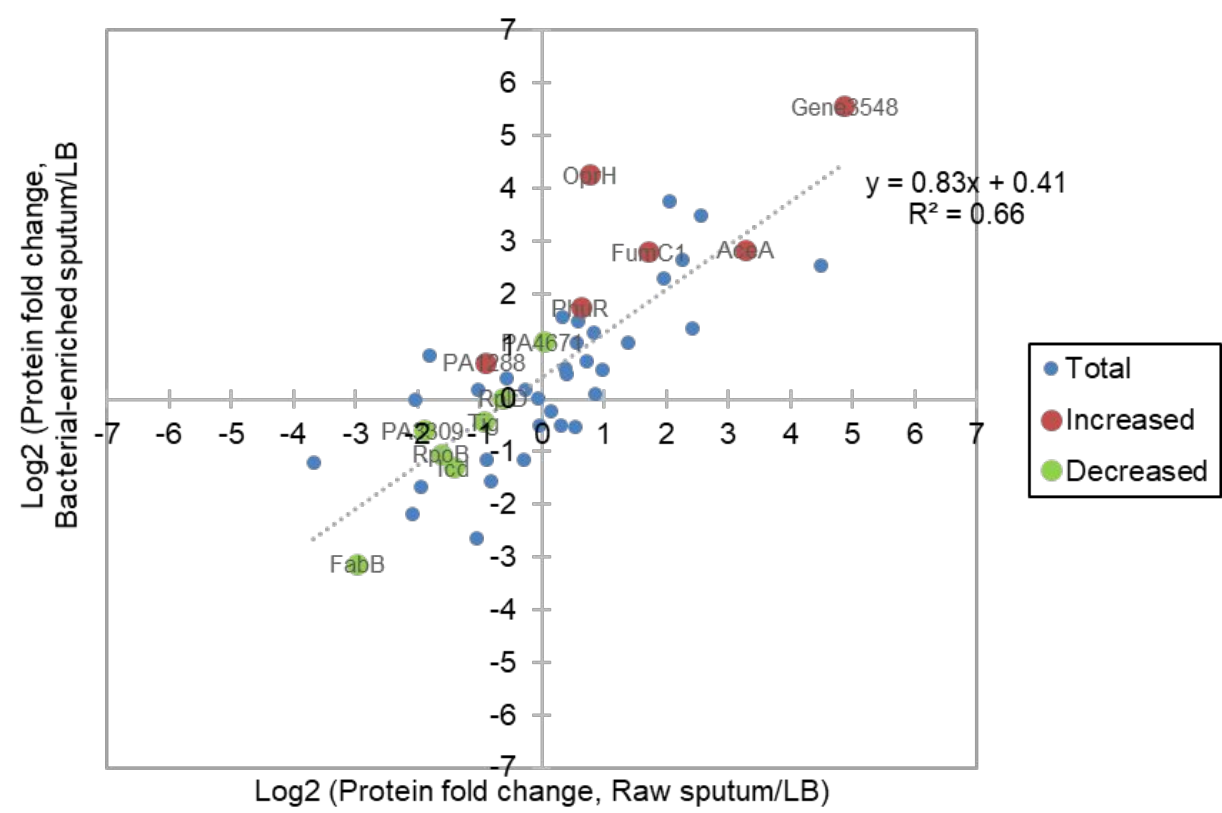

Figure S3A. Comparison of PA proteome before and after the bacterial-enrichment procedures. The CF sputum sample was aliquoted so that one aliquot of the sample was processed with bacterial-enrichment procedures, while another aliquot was kept on ice and processed as the raw sputum for proteome comparison (Fig. 2A). The PA proteomes of sputum samples were compared with the PA ex vivo proteomes on LB medium condition. Results showed that for PA proteins that could be quantified before and after the bacterial enrichment procedures, these proteins showed a general consistence in the relative abundance in PA proteome, suggesting that the bacterial-enrichment procedures used in this study did not significantly alter the proteome profiles of PA in CF sputum. The Increased/Decreased proteins that were identified through the analysis of 35 sputum samples are highlighted in figures. 


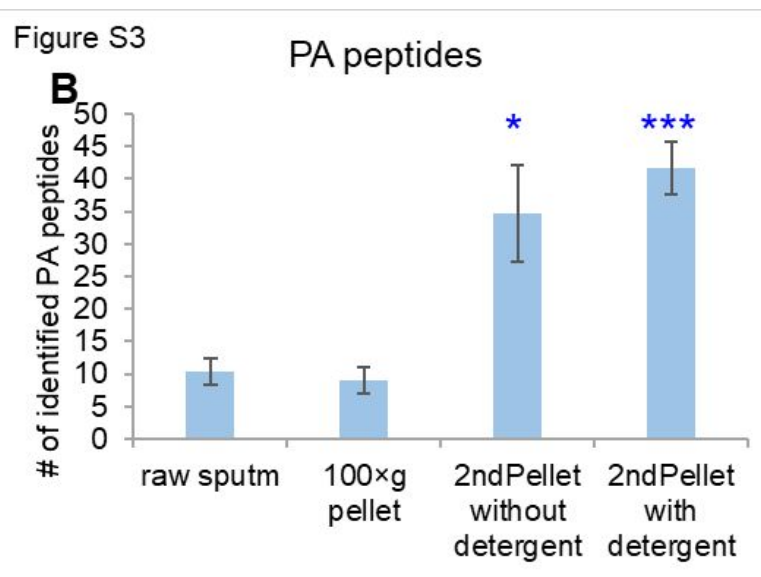

Myeloperoxidase (MPO), P05164

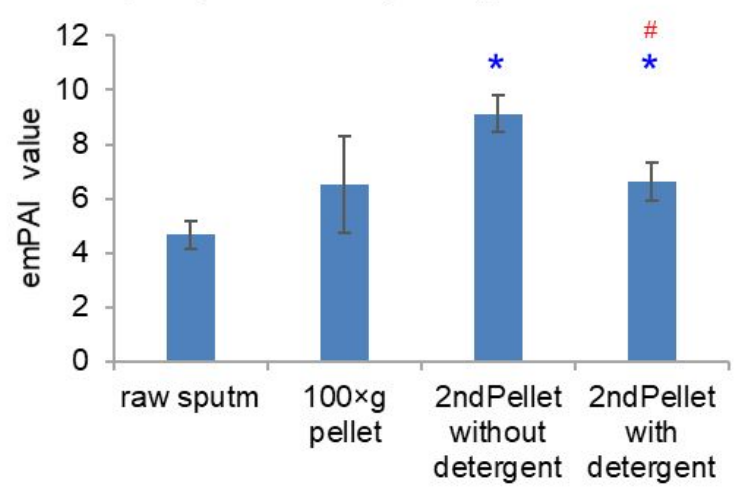

Keratin(KRT1), P04264

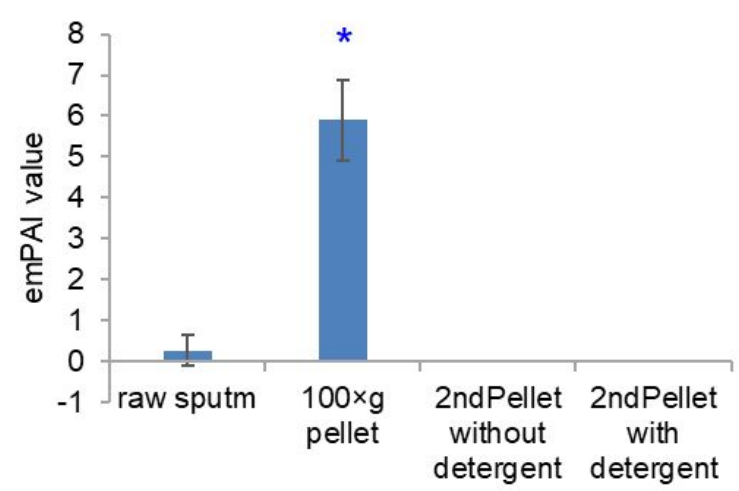

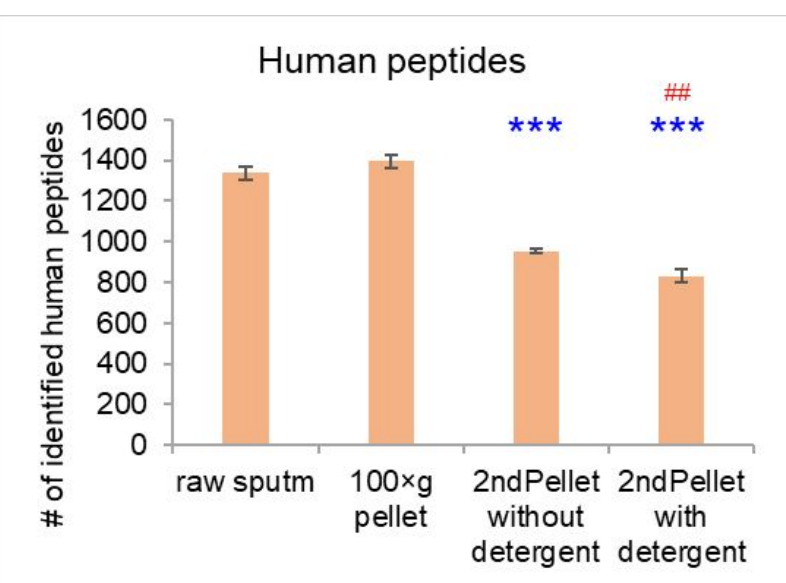

Lactotransferrin (LTF), P02788

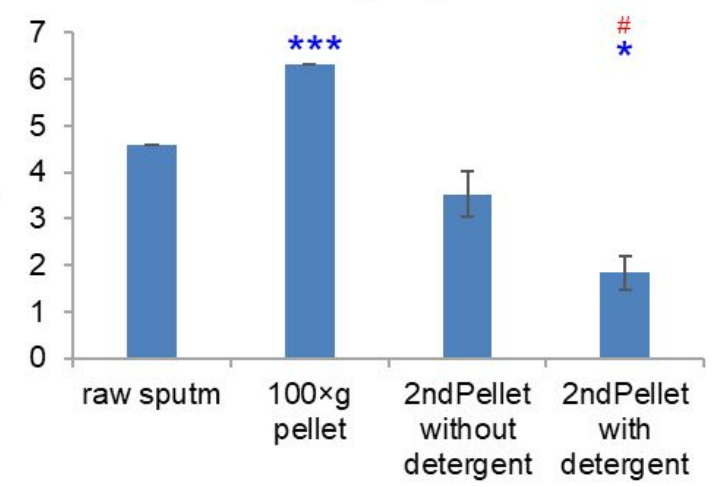

Glyceraldehyde-3-phosphate dehydrogenase (GAPDH), P04406

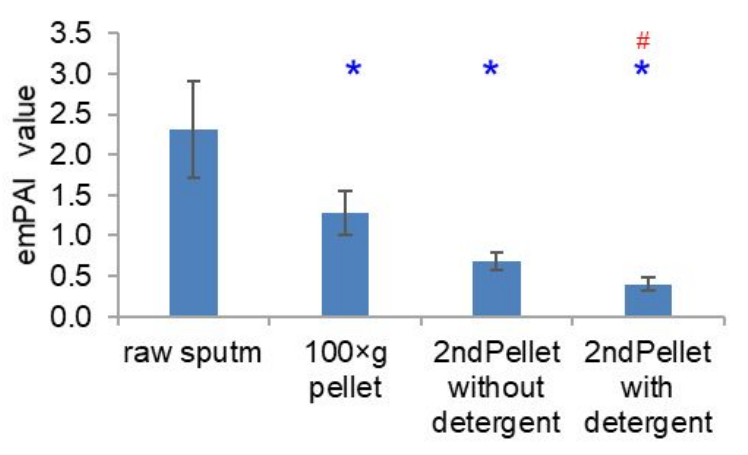

Figure S3B. Comparison of PA proteome before and after the bacterial-enrichment procedures. The CF sputum samples were aliquoted to prepare as raw sputum, the pellet collected with $100 \times \mathrm{g}$ centrifugation $(100 \times \mathrm{g}$ pellet $)$, the second centrifugation pellets after the $10,000 \times \mathrm{g}$ centrifugation with or without additional TX-100 and Brij-58 treatment. Proteomics data were collected with LTQ-XI (Thermo-Fisher). Greater number of PA peptides were identified with the bacterial enriched pellets. Spectral counting analysis with Exponentially Modified Protein Abundance Index (emPAI) showed the benefits of reduction of abundant host proteins LTF, KRT1, MPO and GAPDH with the separation of $100 \times$ g pellet or with the detergent treatment. Standard error bars indicate standard deviation of three technical replicates of LC-MS/MS analysis. ANOVA analysis comparison with raw sputum * $\mathrm{P}<0.05$, ***, $\mathrm{P}<0.001$. ANOVA analysis comparison between detergent treatments, $\#<0.05, \# \#<0.01$. 
Figure S4

A

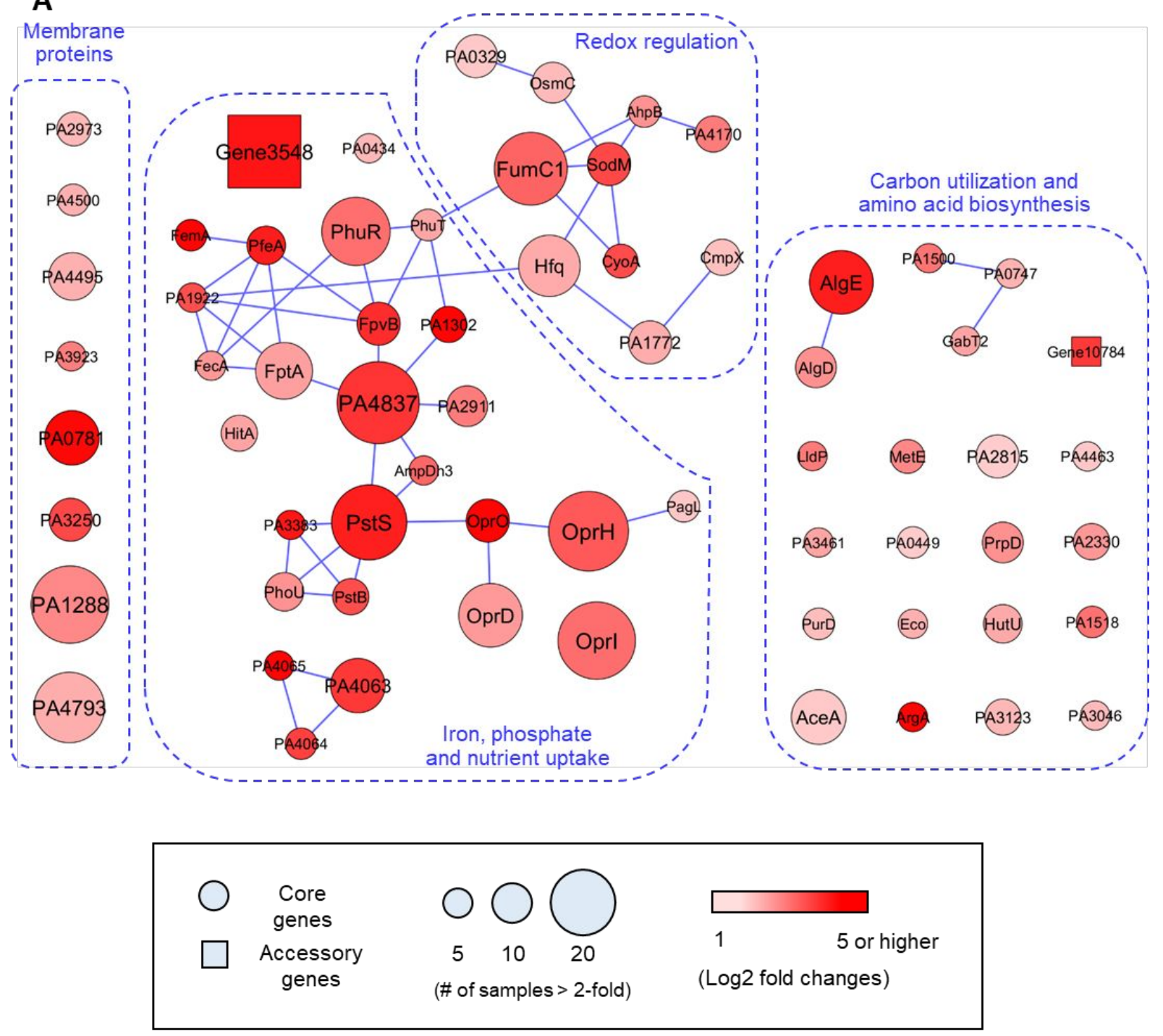

Figure S4. PA protein network up-regulated (A) or down-regulated (B) in CF airways. The network includes 67 increased proteins and 117 decreased proteins that were identified with 2-fold or greater fold-changes with at least $5 \mathrm{CF}$ sputum samples compared with the ex vivo cultured samples. The nodes represent proteins, and the edges indicate protein interaction information which was obtained with STRING (version 10.0). The node shape indicates whether the PA protein is classified as a core gene or accessory gene. The node size is correlated with the number of sputum samples identified with 2 -fold or greater changes. The bigger the node size means the increases were more frequently found in CF sputum samples. The node color indicates the extent of increases (red) or decreases (green) of the averaged protein fold change. The network is visualized with Cytoscape (version 3.4.0). 
Figure S4
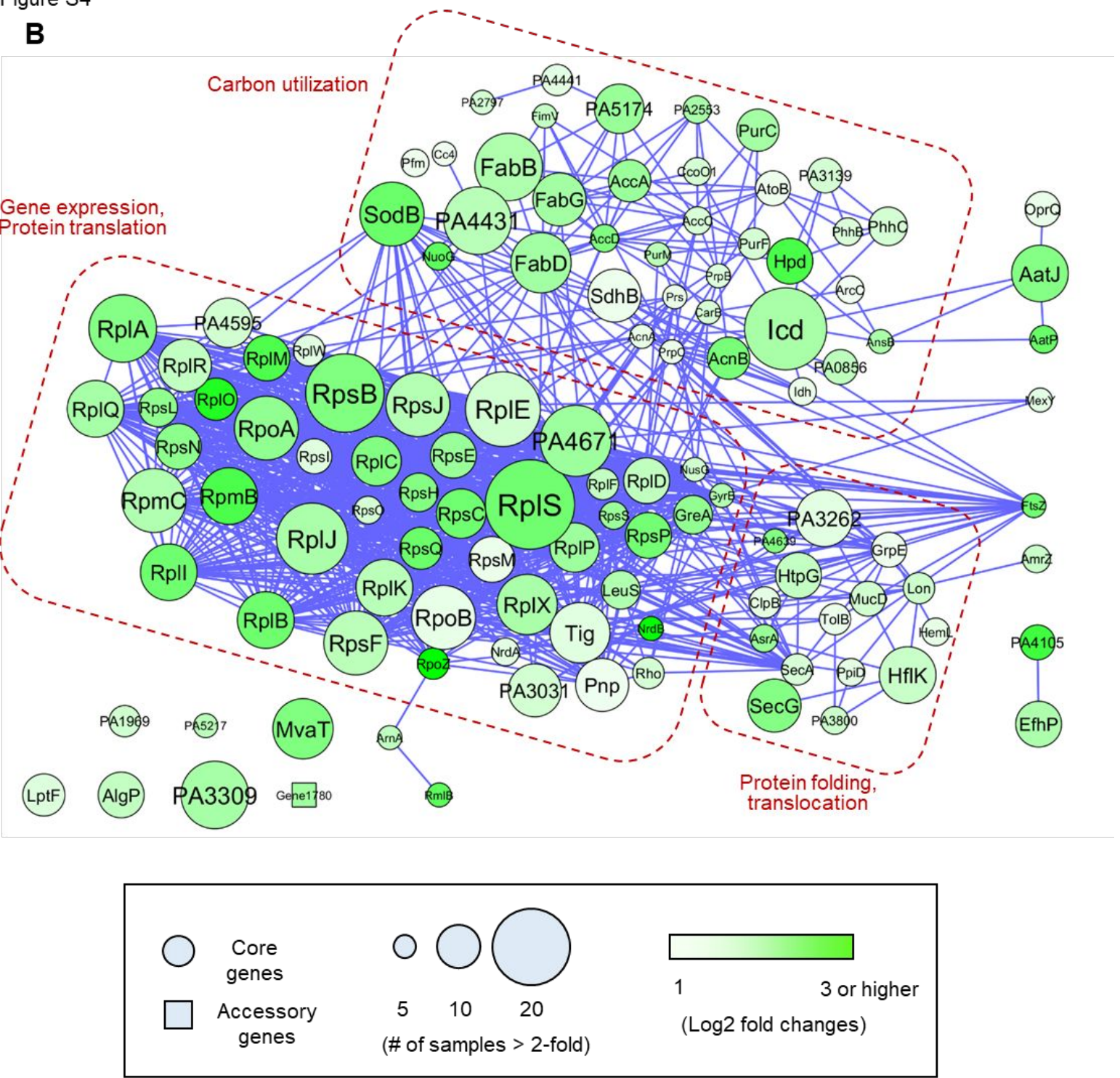

Figure S4. PA protein network up-regulated (A) or down-regulated (B) in CF airways. The network includes 67 increased proteins and 117 decreased proteins that were identified with 2-fold or greater fold-changes with at least $5 \mathrm{CF}$ sputum samples compared with the ex vivo cultured samples. The nodes represent proteins, and the edges indicate protein interaction information which was obtained with STRING (version 10.0). The node shape indicates whether the PA protein is classified as a core gene or accessory gene. The node size is correlated with the number of sputum samples identified with 2-fold or greater changes. The bigger the node size means the increases were more frequently found in CF sputum samples. The node color indicates the extent of increases (red) or decreases (green) of the averaged protein fold change. The network is visualized with Cytoscape (version 3.4.0). 
Figure S5

A

Glycolysis/Glyconeogenesis

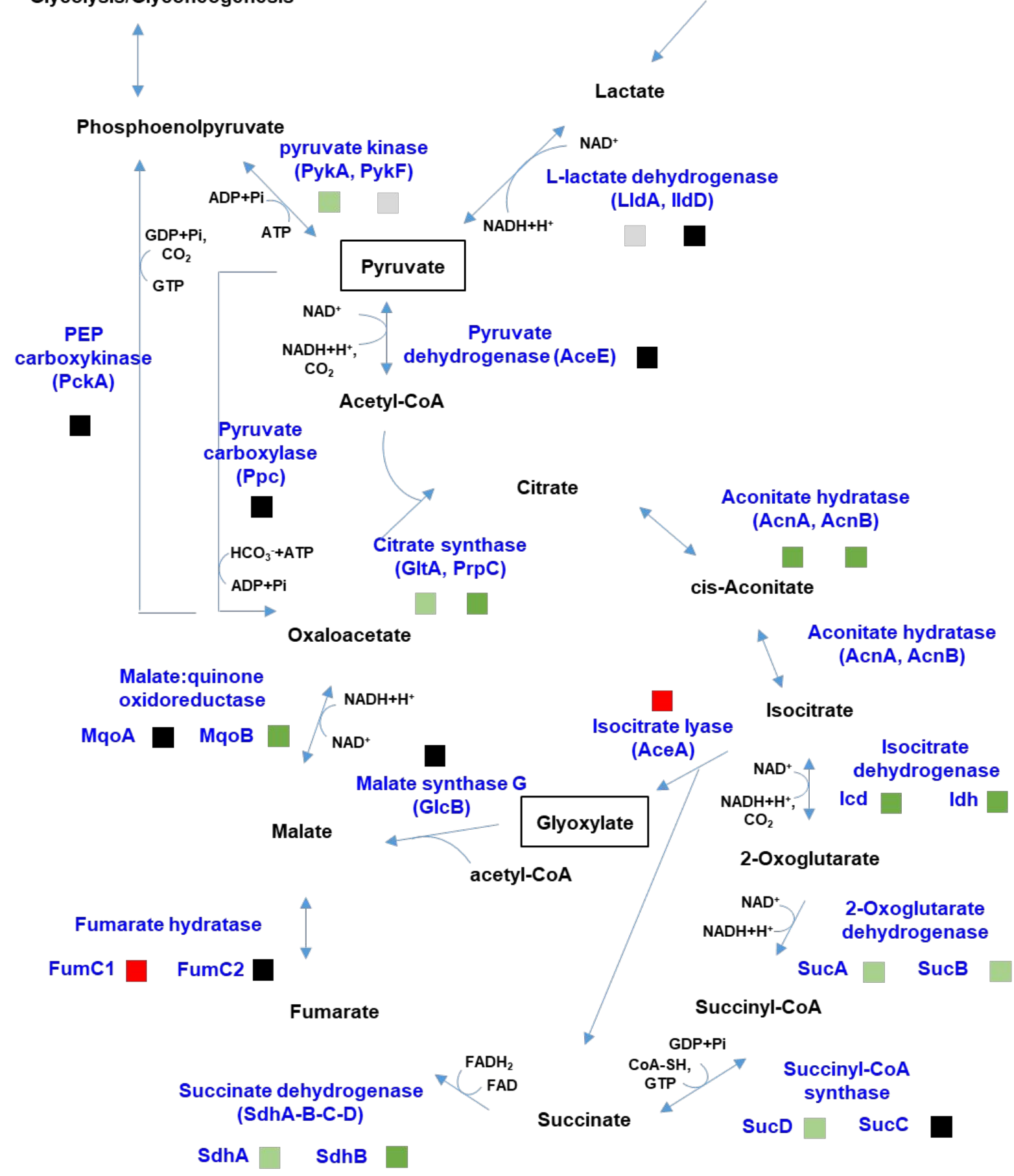

Phosphoenolpyruvate

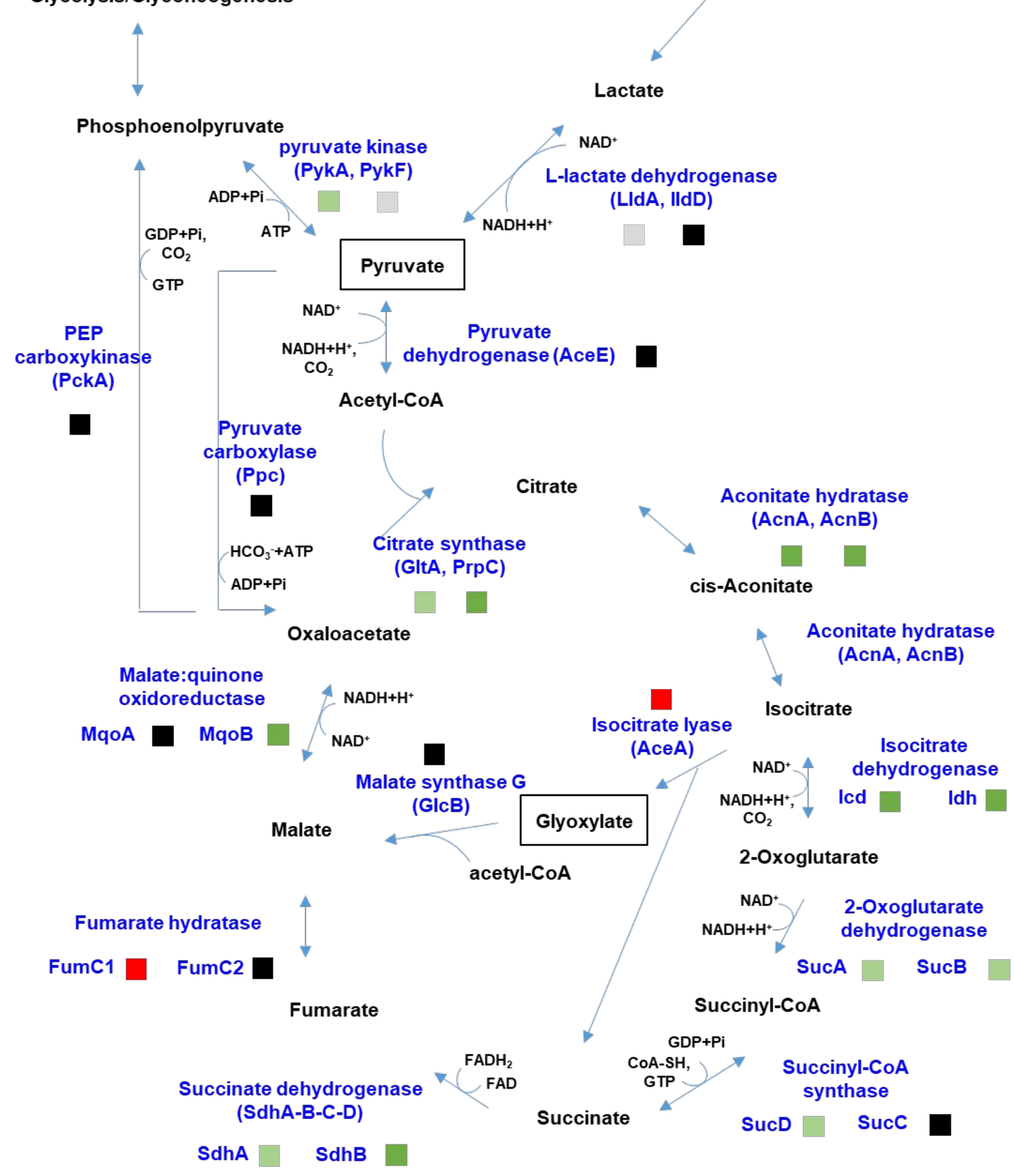

te transport by L-lactate permease (LIdP)

\begin{tabular}{|l|lll} 
Increased $(P<0.05)$ & Decreased $(P<0.05)$ & $\begin{array}{l}\text { Detected (fold changes } \\
\text { not statistical significant })\end{array}$ \\
$\square>2$ fold & $1-2$ fold & $>2$ fold $\quad 1-2$ fold & dected
\end{tabular}




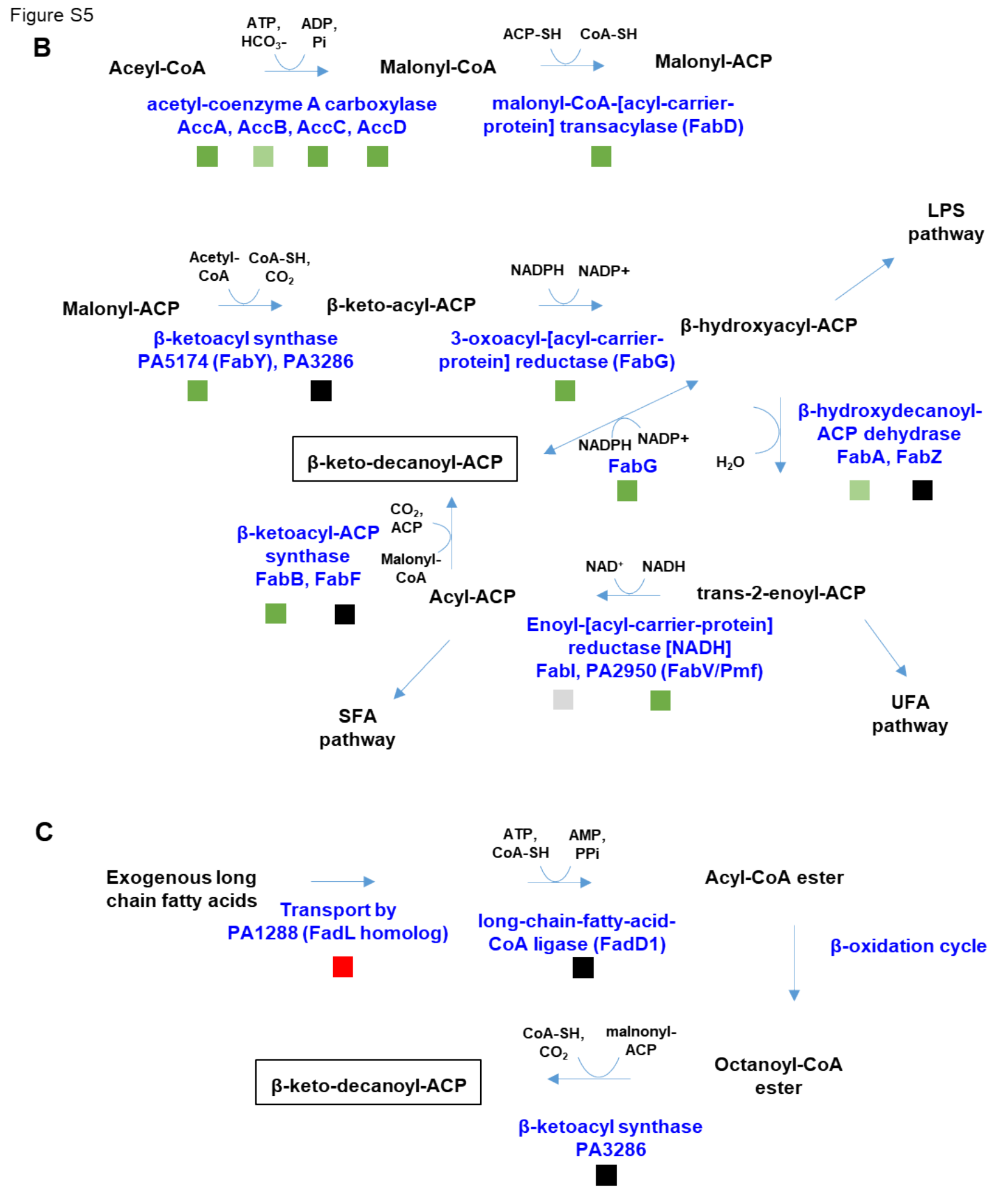

\begin{tabular}{|c|c|c|c|c|c|}
\hline \multicolumn{2}{|c|}{ Increased $(P<0.05)$} & \multicolumn{2}{|c|}{ Decreased $(P<0.05)$} & \multirow{2}{*}{$\begin{array}{l}\text { Detected (fold changes } \\
\text { not statistical significant) }\end{array}$} & \multirow{2}{*}{ Not detected } \\
\hline$>2$ fold & $1-2$ fold & $>2$ fold & 1-2 fold & & \\
\hline
\end{tabular}


Figure S5

D

Phosphomannose isomerase (AlgA)

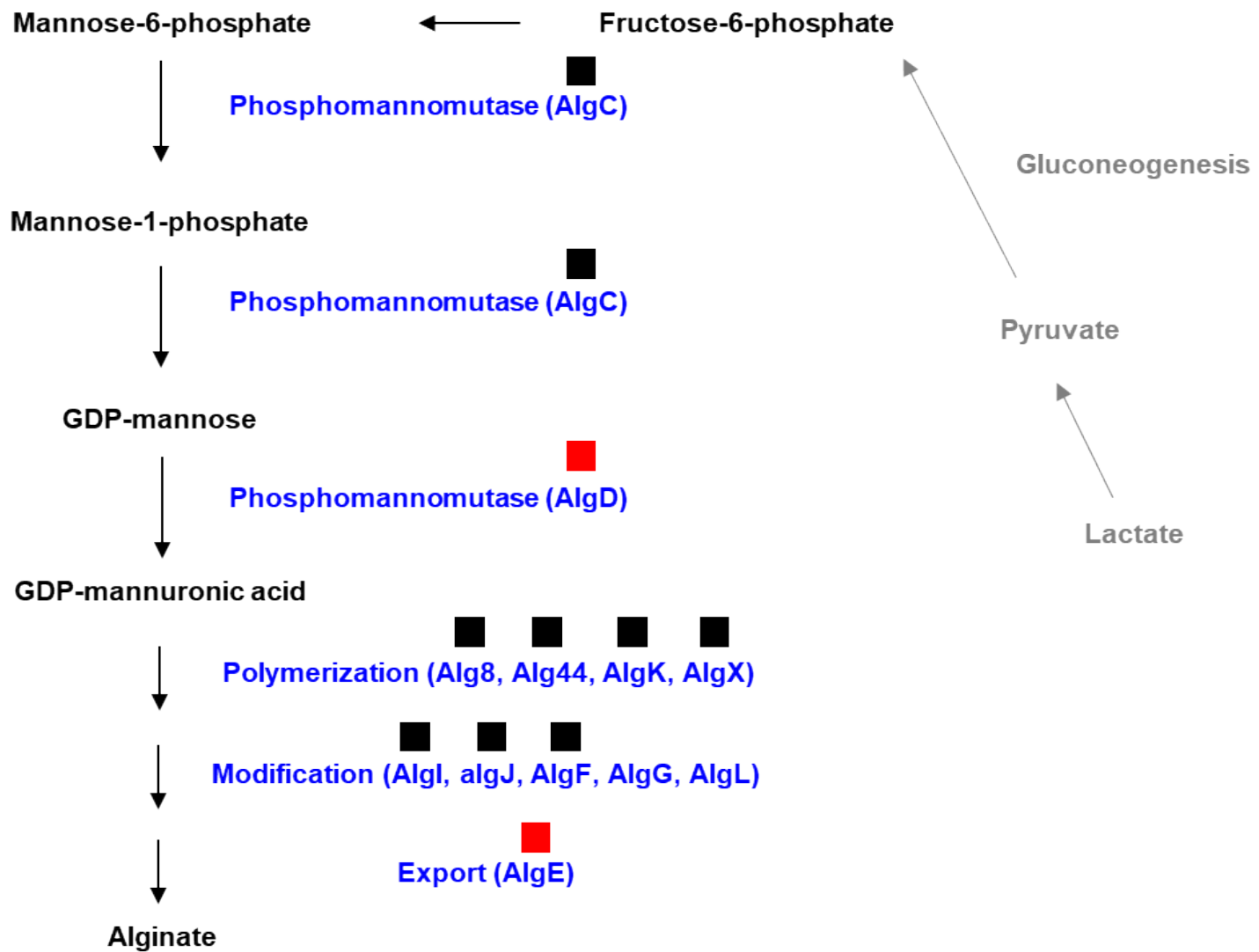

Alginate

\begin{tabular}{|l|l|}
\hline $\begin{array}{l}\text { Increased }(P<0.05) \\
1-2 \text { fold }\end{array} \quad \begin{array}{l}\text { Detected (fold changes } \\
\text { not statistical significant) }\end{array}$ \\
\hline
\end{tabular}

Figure S5. Carbon metabolic remodeling of PA in vivo. A) TCA cycle and glyoxylate cycle. Enzymes in lactate utilization and glyoxylate cycles are up-regulated in vivo, as well as fumarate hydratase FumC1. B-C) Fatty acid metabolic pathways of endogenous biosynthesis (B), and utilization of exogenous fatty acid product (C). The diagram is adapted from Yuan et al. (2012). Many enzymes in fatty acid endogenous biosynthesis is down regulated in vivo, but enzymes functioning in utilization of exogenous fatty acid are up-regulated. (D) Alginate biosynthesis pathway. For all panels, increased proteins are shown in red. Decreased proteins are shown in green, with the dark green as fold change $>$ 2, and light green as fold change in between 1-2 fold. Markers in black indicate that the enzymes were detected, but fold changes were not statistical significant. Markers in grey indicate that the enzymes were not detected. 
Figure S6

Control proteins

PA5554 AtpD

R.EAPSYADQAGGNELLETGIK.V $[111,130]$

Transitions

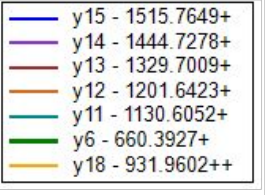

0

(1) Ex vivo isolates

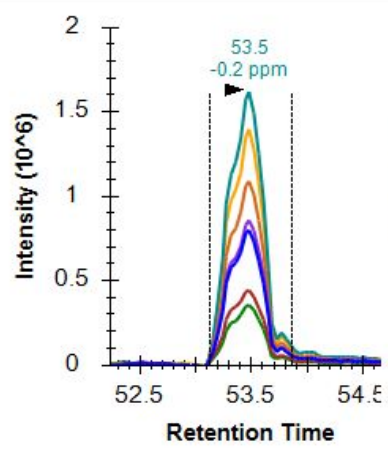

(2) Sputum enriched for bacteria

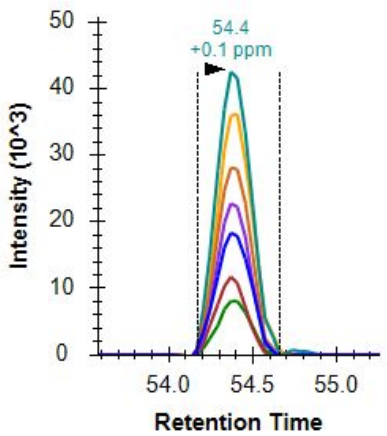

(3) Raw sputum

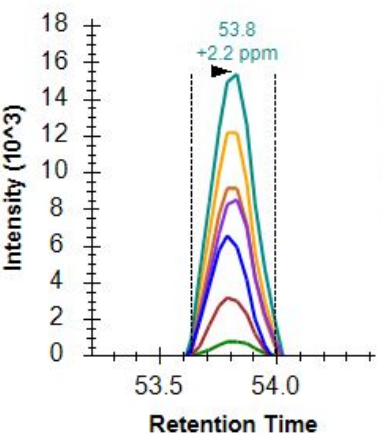

Normalized

peak area

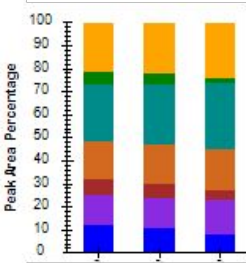

(1) (2) (3)

Porins

PA4710 PhuR

R.SGTGTNLDTGADSPR.D $[399,413]$

Transitions

\begin{tabular}{|c|}
\hline $\begin{array}{l}\text { y12 - } 1203.5600+ \\
\text { y11 }-1146.5386+ \\
\text { y10 }-1045.4909+ \\
\text { y9 }-931.4480+ \\
\text { y7 }-703.3369+ \\
\text { y6 }-602.2893+ \\
\text { y5 }-545.2678+ \\
\text { y4 }-474.2307+ \\
\text { y12 - } 602.2836++ \\
\text { b5 }-404.1776+ \\
\text { b7 - 631.3046+ }\end{array}$ \\
\hline
\end{tabular}

(1) Ex vivo isolates

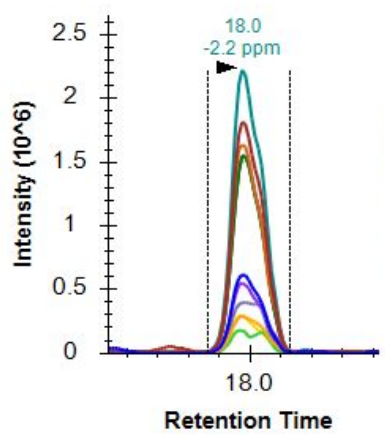

(2) Sputum enriched for bacteria

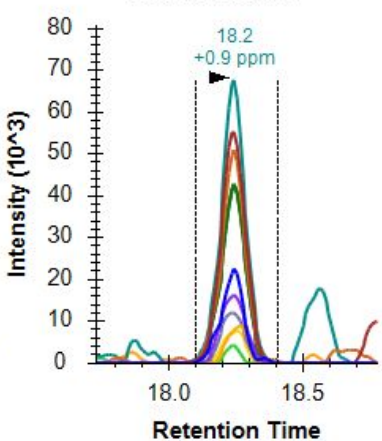

(3) Raw sputum

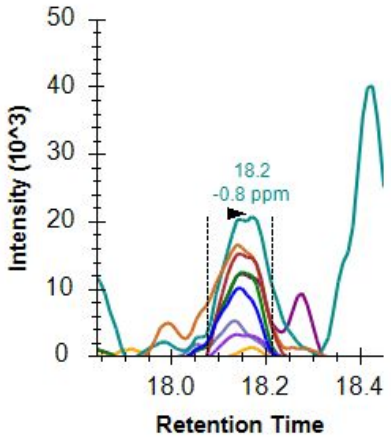

Normalized peak area

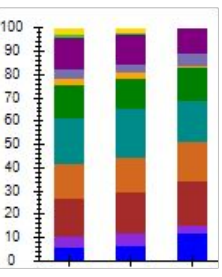

(1) (2) (3)

\section{GENE3548}

\section{K.EIPQTINVVTQDEIK.A $[163,177]$}

Transitions

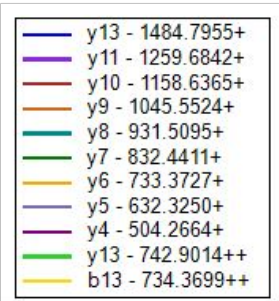

(1) Ex vivo isolates

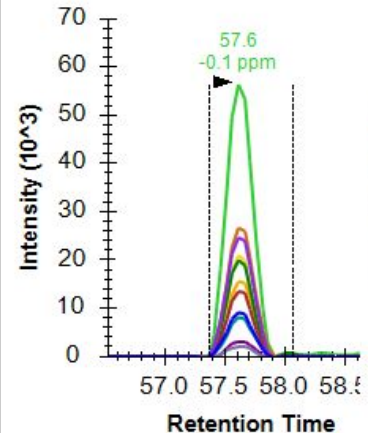

(2) Sputum enriched for bacteria

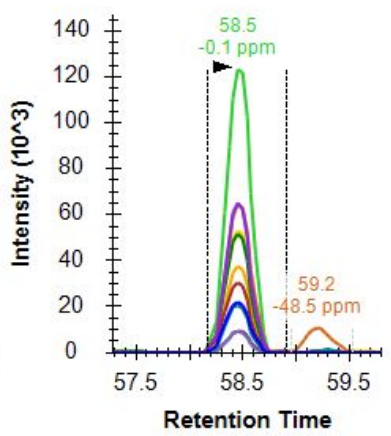

(3) Raw sputum

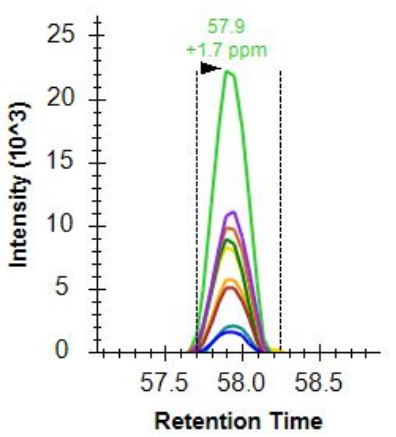

Normalized peak area

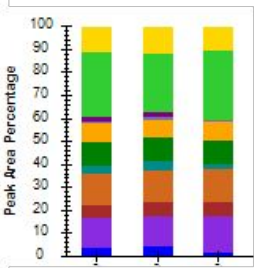

(1) (2) (3) 
Figure S6

Glyoxylate cycle enzymes

PA2634 AceA

R.LASNLFQFR.K [318, 326]

Transitions

\begin{tabular}{|c|}
\hline $\begin{array}{l}\text { y8 }-982.5105+ \\
\text { y7 }-911.4734+ \\
\text { y6 }-824.4413+ \\
\text { y5 }-710.3984+ \\
\text { y4 }-597.3144+ \\
\text { y3 }-450.2459+ \\
\text { y2 }-322.1874+ \\
\text { b4 }-386.2034+ \\
\text { b5 }-499.2875+ \\
\text { b8 }-921.4829+\end{array}$ \\
\hline
\end{tabular}

(1) Ex vivo isolates

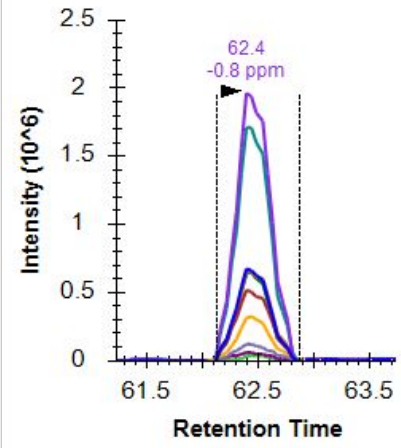

(2) Sputum enriched

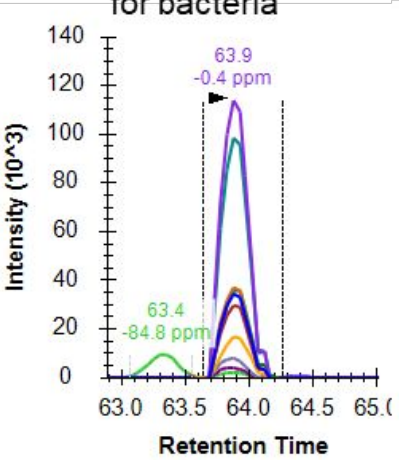

(3) Raw sputum

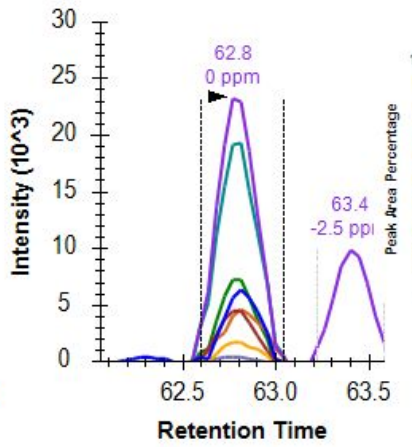

Normalized peak area

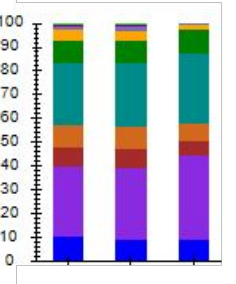

(1) (2) (3)

Alginate biosynthesis proteins

PA3540 AlgD

K.SPIVEPGLEALLQQGR.Q $[44,59]$

Transitions

(1) Ex vivo isolates

(2) Sputum enriched

(3) Raw sputum

Normalized for bacteria peak area

\begin{tabular}{|c|}
\hline $\begin{array}{l}\text { y13 }-1409.7747+ \\
\text { y12 }-1310.7063+ \\
\text { y11 }-1181.6637+ \\
\text { y7 }-785.4628+ \\
\text { y4 - } 488.2576+ \\
\text { y14 }-761.9330++ \\
\text { y11 }-591.3355++ \\
\text { b5 }-526.2871+\end{array}$ \\
\hline
\end{tabular}
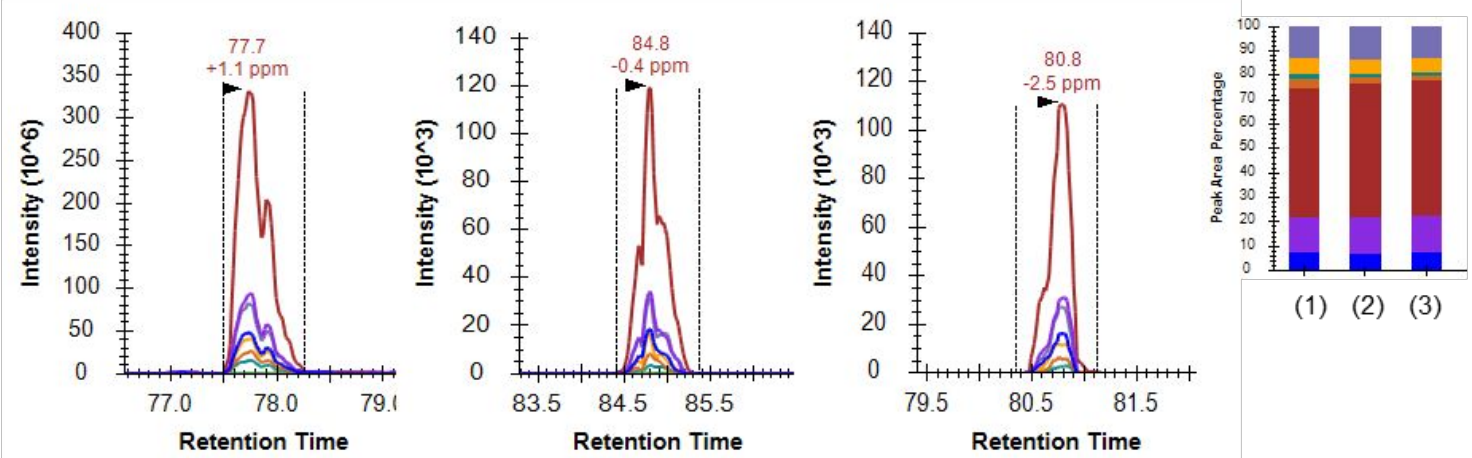

(1) (2) (3)

K.AGVDFGVGTNPEFLR.E $[146,160]$

Transitions

(1) Ex vivo isolates

(2) Sputum enriched for bacteria

(3) Raw sputum

Normalized peak area
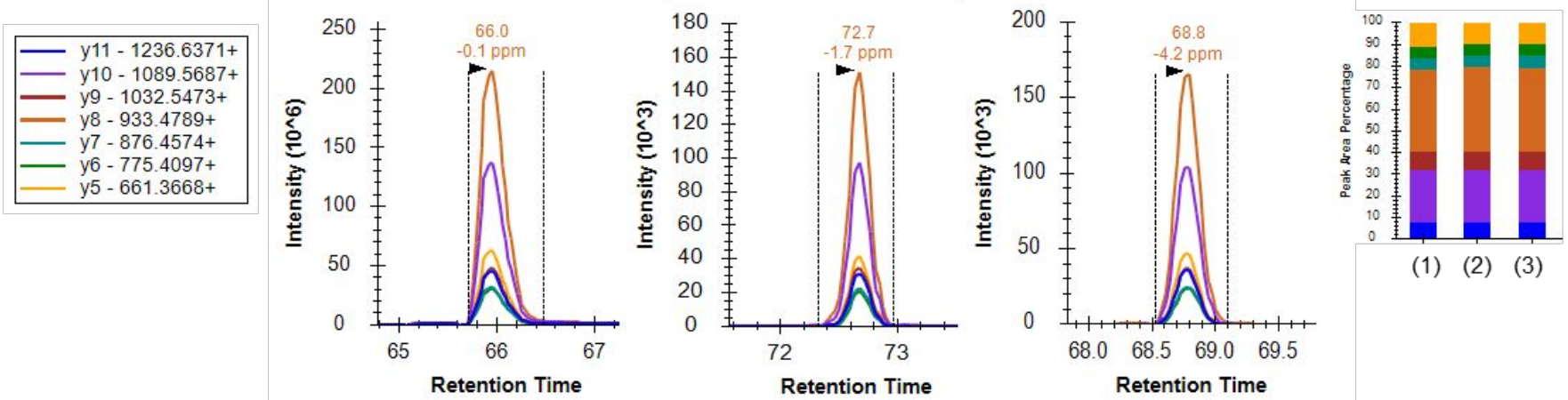

(1) (2) (3) 
Figure S6

Alginate biosynthesis proteins

PA3544 AlgE

K.QSGDVNAFGVDLGLR.W $[303,317]$

Transitions

(1) Ex vivo isolates

(2) Sputum enriched for bacteria

(3) Raw sputum

Normalized

- $\mathrm{y} 11-1160.6422+$ - y10 - 1061.5738t

- y9 - 947.5309+

- y8 - 876.4938+

- y7 - 729.4254+

- y $672.4039+$

y4 - 458.3085+
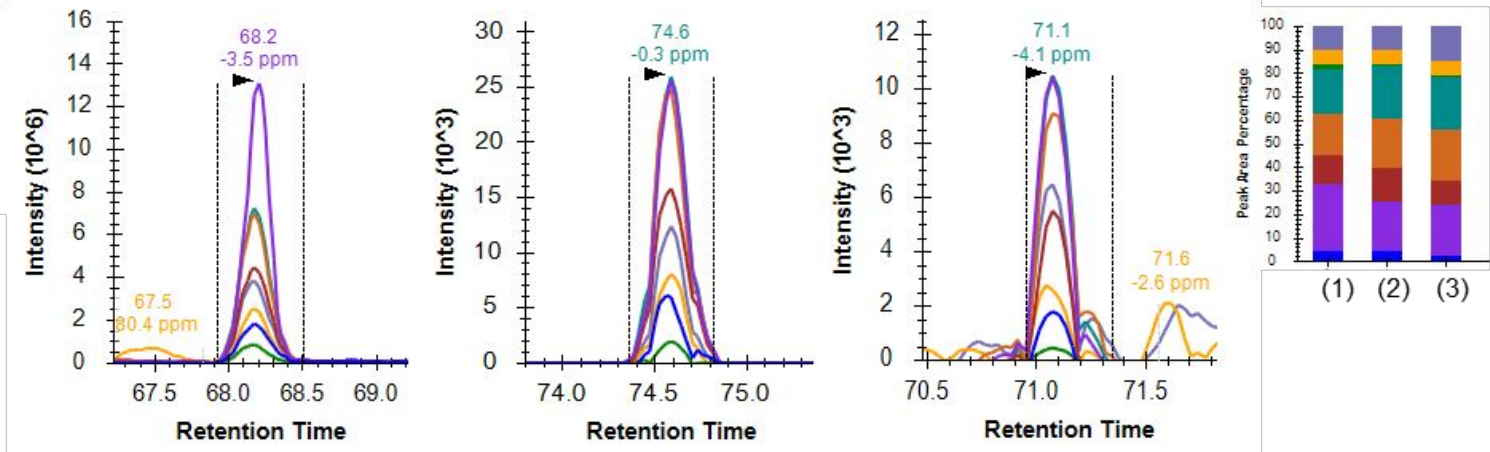

(1) (2) (3)

K.DIGQELDLVVTK.Y $[425,436]$

Transitions

(1) Ex vivo isolates

(2) Sputum enriched

(3) Raw sputum

Normalized for bacteria peak area

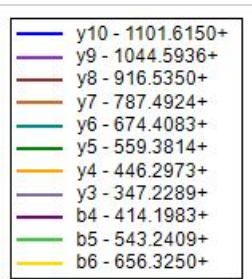

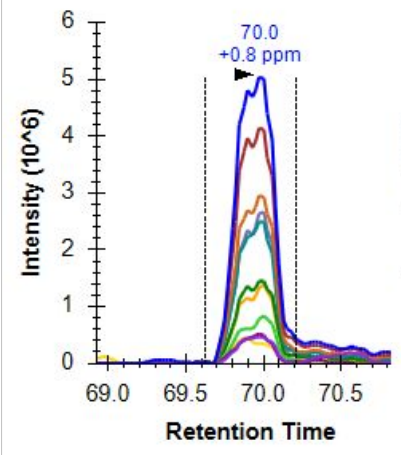

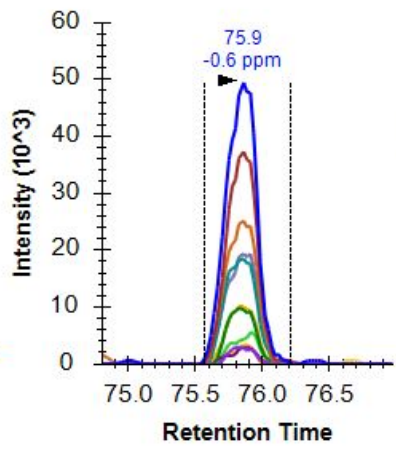

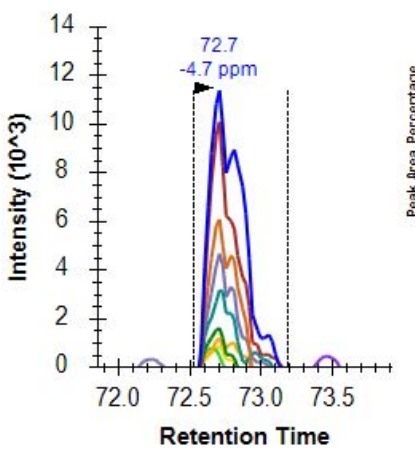

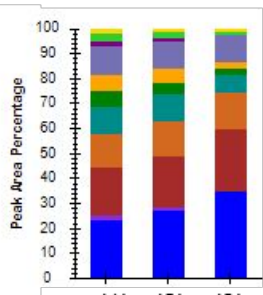

(1) (2) (3)

Figure S6. Spectrum examples of parallel reaction monitoring (PRM) assays to detect PA proteins with CF sputum samples. PRM signals were visualized with Skyline (version 4.1). Transitions with the most abundant signals for each peptide were listed. The normalized peak area shows the consistence of transition signals for each PA protein detected with (1) the ex vivo PA isolates, (2) the CF sputum samples processed with bacterial enrichment method, or (3) the raw sputum which was not processed with bacteria enrichment. 